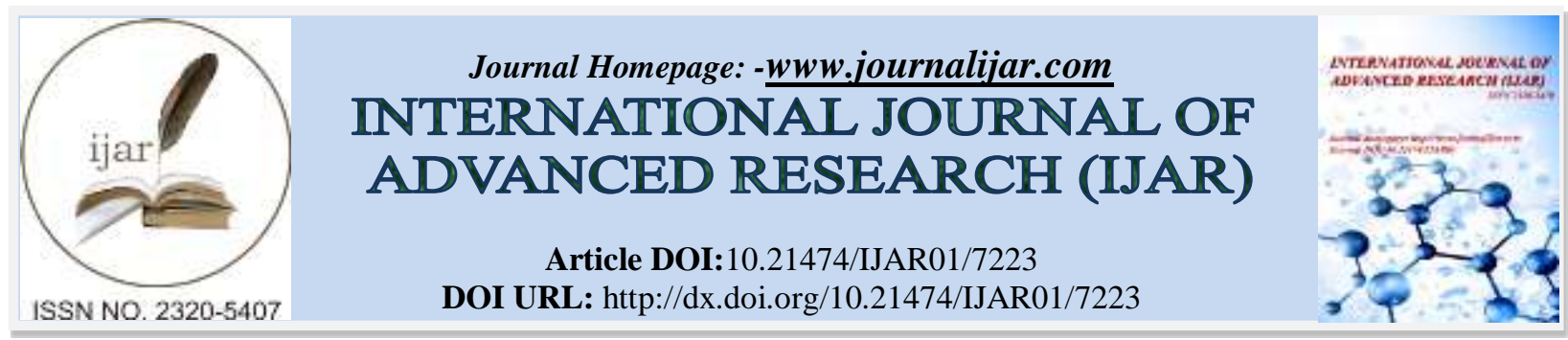

RESEARCH ARTICLE

\title{
ANTHROPOMETRIC VARIABLES OF BRAZILIAN AIR FORCE PILOTS FOR ADJUSTMENT TO THE T-27 AIRCRAFT COCKPIT.
}

\section{Thiago Augusto Rochetti Bezerra ${ }^{1,7}$, Phelipe Henrique Cardoso de Castro ${ }^{2,7}$, Gabriel Guidorizzi Zanetti ${ }^{3,7}$,} Leandra Cristina Benetti Campos ${ }^{4,7}$, Juliana Cristina Viola ${ }^{4}$, Grace Guindani ${ }^{1,5}$, Rodrigo Romero Faria Santos ${ }^{6,7}$ and Fábio Angioluci Diniz Campos ${ }^{1,7}$.

1. Universidade da Força Aérea, Programa de Pós-graduação em Desempenho Humano Operacional/ PPGDHO, Rio de Janeiro, RJ, Brasil

2. Programa Interstitucional de Pós Graduação em Ciências Fisiológicas- PIPGCF UFSCar/ UNESP, São Carlos, SP, Brasil.

3. Escola de Enfermagem de Ribeirão Preto - Universidade de São Paulo. Ribeirão Preto, SP, Brasil .

4. Universidade Metodista de Piracicaba- UNIMEP, Programa de Pós Graduação em Ciências do Movimento Humano, Piracicaba, SP, Brasil.

5. Instituto de Ciências da Atividade Física - ICAF, Comissão de Desportos da Aeronáutica- CDA, Rio de Janeiro, RJ, Brasil.

6. Faculdade de Medicina de Ribeirão Preto, Programa de Pós Graduação em Ciências da Saúde Aplicadas ao Aparelho Locomotor, Ribeirão Preto, SP, Brasil.

7. Academia da Força Aérea, Pirassununga, SP, Brasil.

\section{Manuscript Info}

Manuscript History

Received: 06 April 2018

Final Accepted: 08 May 2018

Published: June 2018

Keywords:-

Anthropometry. Ergonomics.

Occupational health. Flight safety. Pilots of the Brazilian Air Force.

\section{Abstract}

The present study aimed to verify if the ergonomic design of the cockpit of the T-27 aircraft is compatible with the anthropometric profile of Brazilian young people who join the Air Force Academy (AFA). The anthropometric measures related to flight safety were: body mass, height, sitting height, height of the position of the eyes, sitting shoulder height, functional distance (upper limbs), distance from knee to hip, and sitting knee height. Descriptive statistics, comparison of suitability between the sexes, and percentage distribution for each variable were performed, analyzing the values between the $5^{\text {th }}$ and $95^{\text {th }}$ percentiles and their compatibility with the anthropometric requirements of the aircraft. It was evidenced that, for the cockpit of the T-27 Tucano aircraft, the percentages of the male population presented greater suitability (up to 90\%) in relation to the female (below 90\%). It was concluded that there is a need for new analyzes of the national anthropometric profile, aiming at optimizing the dimensions of pilot cabins and providing information to the target population in the preparation of future aircraft projects.

Copy Right, IJAR, 2018,. All rights reserved.

\section{Introduction:-}

The Aviator Officers Training Course (CFOAv) is four years long, with flight instructions in the EMB 312 T-27 Tucano aircraft. In order for the aviation cadet to carry out the flight instructions, the T-27 has peculiarities that involve an anthropometric suitability profile for flight safety. The T-27 aircraft contains an emergency seat ejection 
mechanism and the peculiarities of the ejector seat imply the need to establish anthropometric limits, aiming at the safety of the pilot in case of ejection, as presented in Table 1.

Table 1:-Antropometric Limits of the aircraft T-27

\begin{tabular}{|l|l|l|}
\hline Antropometric Limit & Minimum & Maximum \\
\hline Body Mass (kg) & 58,65 & 93,53 \\
\hline Body Mass Plus Equipment (kg) & 68,17 & 105,65 \\
\hline Stature (cm) & 164 & 187,3 \\
\hline Seated height (cm) & 85,1 & 97,4 \\
\hline Height of the eye position (cm) & 73,8 & 85,9 \\
\hline Seated shoulder height (cm) & 53,5 & 64,4 \\
\hline Functional distance (cm) & 74,6 & 90,3 \\
\hline Distance between knee and hip sitting (cm) & 55,1 & 65,2 \\
\hline Knee height sitting (cm) & 50,5 & 59,8 \\
\hline
\end{tabular}

SOURCE: Embraer (2008)

These anthropometric limits are defined based on the reduction in operational capacity of a pilot with an anthropometric profile outside these parameters and impairment in the ejection if the critical limits are extrapolated, resulting in damage to the physical integrity of the pilot, with possible consequences to their health. If the ejection exceeds the acceleration limits, it will cause damage to the pilot's spine and the opening of the parachute may be impaired if the seat falls outside the tolerance range ${ }^{1-3}$.

As an example, the "knee to hip" dimension is critical as the projection of the seat can injure the knees in case of ejection, causing them to collide with the top of the panel due to the positioning of the pilot.

The objective of this research was to verify if the ergonomic design of the cockpit of the T-27 aircraft, used in the advanced aerial training at the Air Force Academy (AFA), is appropriate for the anthropometric profile of the young pilots, with respect to dimensions relevant to accommodation and flight safety.

\section{Methods:-}

\section{Participants:-}

The target population of the study consisted of all the Brazilian young people who joined the AFA, in the Aviator Officers Training Course (CFOAv), Steward Officers Training Course (CFOInt), and Infantry Officers Training Course (CFOInf), composed of 741 cadets. The population and sample distribution can be observed in Tables 2 .

Table 2:-Distribution of the population

\begin{tabular}{|l|l|l|}
\hline Frame & Sex & Total \\
\hline Aviator Officers Training Course & Male & 18 \\
& Female & 474 \\
\hline Steward Officers Training Course & Male & 66 \\
& Female & 100 \\
\hline Infantry Officers Training Course & Male & 83 \\
\hline Total & \multicolumn{2}{|l}{} \\
\hline
\end{tabular}

\section{Procedures:-}

Initially, the participants to be evaluated received clarification on the measures that would be collected. Next, after passing a five day theoretical and practical course, with a workload of 20 hours/class, in order to standardize the procedures provided for in the Manual of Anthropometric Measures ${ }^{4}$, and being familiarized with the equipment, twelve people were selected to compose a team that performed the data collection. In the period from October to November 2017, the Brazilian Air Force Academy collected the following anthropometric measures: body mass, height, sitting height, height of the position of the eyes, sitting shoulder height, functional distance (upper limbs), distance from knee to hip, and sitting knee height. 
For the measurement of body mass, a Toledo® Digital Scale, Model 2098 PP, was used, with a capacity of 200kg and a precision of $50 \mathrm{~g}$. For the linear measurements, a GPM ${ }^{\circledR}$ anthropometer was utilized, with a measuring range from 0 to $210 \mathrm{~cm}$, measuring rod $175 \mathrm{~mm}$ in length, and resolution in millimeters. For the functional distance measurement, a $20 \mathrm{~cm} \times 10 \mathrm{~cm}$ wooden block and a millimeter scale fixed to the wall were used. To register the body mass, the evaluated person was positioned on the scale, barefoot, in an orthostatic position, with their back to the scale, wearing a swimsuit (men) or top and shorts (women) ${ }^{4}$.

With the evaluated individual in the sitting position, the evaluator placed the anthropometer behind and slightly to the right of the individual, leaning the fixed rod on the seat and the movable rod aligned to the outer corner of the right eye ${ }^{4}$.

The participant remained in the sitting position and the vertical distance between the seat and the acromion was recorded, the anthropometer fixed rod resting on the seat and the movable rod on the acromion. The volunteer was required to keep their thighs parallel, knees at $90^{\circ}$ flexion, feet aligned to the thighs, and upper limbs with elbows at $90^{\circ}$ flexion and palms facing inwards. This measurement was performed with the participant standing, with their back and buttocks in contact with the wall, shoulder extended at $90^{\circ}$, with the palm of the hand facing the ground, elbow in extension, flexion of the fingers at $90^{\circ}$, and thumb aligned to the longitudinal axis of the forearm. The evaluator stood next to another wall, with a fixed millimeter scale, and pushed the volunteer's shoulder back. A block of wood was used in contact with the tip of the thumb, to record the measurement obtained. The procedure was performed three times, and the measure considered as the average of the results. ${ }^{4}$.

The vertical distance between the suprapatellar region and the foot support surface was measured in the sitting position using the anthropometer; the fixed rod was leaned against the support surface of the foot and the movable rod was leaned against the suprapatellar region. The feet of the participant remained parallel to the thighs and the knees at an angle of 90 degrees. With the volunteer in the orthostatic position (standing, erect position, arms along the body, feet together, head parallel to the ground), they performed apnea while the evaluator leaned the anthropometer on the vertex of the participant. To ensure the accuracy of the measure, the volunteer was barefoot. The participant sat on a $50 \mathrm{~cm}$ high surface, with the head parallel to the ground, and after a maximum inspiration, the evaluator positioned the anthropometer on the vertex, taking three measurements and considering the average of the three. The hip and knee angles remained at $90^{\circ}$.

In the sitting position, the distance between the most posterior point of the gluteus and the most anterior point of the knee was measured. The cadet sat propped up on a platform, leaning against the back of the gluteus; the platform was locked, and the anthropometer was used with the fixed tip in contact with the platform and the movable tip in contact with the knee. The volunteer's feet were aligned to the thighs, and the knee, at an angle of $90^{\circ}$.

This research project was approved by the Ethics Committee of the National Council of Ethics and Human Research (Plataforma Brasil) under number 340.178/2013.

\section{Statistical analysis:-}

The mean, standard error, median, standard deviation, coefficient of variation (CV), minimum value (MIN), maximum value (MAX), and confidence interval (CI) were calculated for the variables age, body mass, height of the position of the eyes, sitting shoulder height, functional distance, and sitting knee height for the CFOAv, CFOInt, and CFOInf cadet population.

The same analyzes of mean, standard error of the mean, median, standard deviation, coefficient of variation (CV), minimum value (MIN), maximum value (MAX), and confidence interval (CI) were performed for the variables of age, height, sitting height and distance from knee to hip, by sex, for the CFOInt and CFOInf cadet samples. In addition to the descriptive statistics, a comparison of suitability between the sexes, based on the parameters of the T27 aircraft, was performed.

The distribution of the percentage of each variable was calculated by sex in order to verify if the values between the $5^{\text {th }}$ and $95^{\text {th }}$ percentiles in the population were compatible with all the anthropometric requirements of the aircraft, thus encompassing $90 \%$ of the AFA cadet population.

Minitab 16, SPSS V17, and Excel 2010 software were used in the statistical processing. 


\section{Results:-}

Table 3 shows the results obtained in the population comprising the CFOAv, CFOIn, and CFOInf.

Table 3:-Results of the population evaluated (CFOAv, CFOIn, and CFOInf.)

\begin{tabular}{|c|c|c|c|c|c|c|c|c|c|c|}
\hline Variable & Sex & $\mathrm{N}$ & average & $\begin{array}{l}\text { standard } \\
\text { error }\end{array}$ & median & $\begin{array}{l}\text { standard } \\
\text { deviation }\end{array}$ & $\mathrm{Cv}$ & Min & Max & Ic \\
\hline Age & $\begin{array}{l}\text { Female } \\
\text { Male }\end{array}$ & $\begin{array}{l}84 \\
657\end{array}$ & $\begin{array}{l}21,32 \\
21,31\end{array}$ & $\begin{array}{l}0,15 \\
0,07\end{array}$ & $\begin{array}{l}21,0 \\
21,0\end{array}$ & $\begin{array}{l}1,41 \\
1,51\end{array}$ & $\begin{array}{l}7 \% \\
7 \%\end{array}$ & $\begin{array}{l}18,0 \\
18,0\end{array}$ & $\begin{array}{l}25,0 \\
26,0\end{array}$ & $\begin{array}{l}0,30 \\
0,12\end{array}$ \\
\hline Body mass & $\begin{array}{l}\text { Female } \\
\text { Male }\end{array}$ & $\begin{array}{l}84 \\
657\end{array}$ & $\begin{array}{l}61,47 \\
74,67\end{array}$ & $\begin{array}{l}0,78 \\
0,34\end{array}$ & $\begin{array}{l}60,7 \\
73,8\end{array}$ & $\begin{array}{l}7,11 \\
8,62\end{array}$ & $\begin{array}{l}12 \% \\
12 \%\end{array}$ & $\begin{array}{l}49,8 \\
50,6\end{array}$ & $\begin{array}{l}83,8 \\
106,7\end{array}$ & $\begin{array}{l}1,52 \\
0,66\end{array}$ \\
\hline $\begin{array}{l}\text { Height of the } \\
\text { eye position } \\
(\mathrm{cm})\end{array}$ & $\begin{array}{l}\text { Female } \\
\text { Male }\end{array}$ & $\begin{array}{l}84 \\
657\end{array}$ & $\begin{array}{l}75,02 \\
79,29\end{array}$ & $\begin{array}{l}0,38 \\
0,12\end{array}$ & $\begin{array}{l}75,1 \\
79,3\end{array}$ & $\begin{array}{l}3,45 \\
3,00\end{array}$ & $\begin{array}{l}5 \% \\
4 \%\end{array}$ & $\begin{array}{l}67,8 \\
69,3\end{array}$ & $\begin{array}{l}85,0 \\
90,0\end{array}$ & $\begin{array}{l}0,74 \\
0,23\end{array}$ \\
\hline $\begin{array}{l}\text { Seated } \\
\text { shoulder } \\
\text { height }(\mathrm{cm})\end{array}$ & $\begin{array}{l}\text { Female } \\
\text { Male }\end{array}$ & $\begin{array}{l}84 \\
657\end{array}$ & $\begin{array}{l}57,02 \\
58,98\end{array}$ & $\begin{array}{l}0,47 \\
0,14\end{array}$ & $\begin{array}{l}56,6 \\
58,8\end{array}$ & $\begin{array}{l}4,31 \\
3,47\end{array}$ & $\begin{array}{l}8 \% \\
6 \%\end{array}$ & $\begin{array}{l}50,7 \\
50,4\end{array}$ & $\begin{array}{l}84,9 \\
88,7\end{array}$ & $\begin{array}{l}0,92 \\
0,27\end{array}$ \\
\hline $\begin{array}{l}\text { Functional } \\
\text { distance }(\mathrm{cm})\end{array}$ & $\begin{array}{l}\text { Female } \\
\text { Male }\end{array}$ & $\begin{array}{l}84 \\
657\end{array}$ & $\begin{array}{l}71,87 \\
77,84\end{array}$ & $\begin{array}{l}0,42 \\
0,16\end{array}$ & $\begin{array}{l}72,1 \\
77,7\end{array}$ & $\begin{array}{l}3,88 \\
4,02\end{array}$ & $\begin{array}{l}5 \% \\
5 \%\end{array}$ & $\begin{array}{l}60,7 \\
57,5\end{array}$ & $\begin{array}{l}82,2 \\
90,8\end{array}$ & $\begin{array}{l}0,83 \\
0,31\end{array}$ \\
\hline $\begin{array}{l}\text { Knee height } \\
\text { sitting }(\mathrm{cm})\end{array}$ & $\begin{array}{l}\text { Female } \\
\text { Male }\end{array}$ & $\begin{array}{l}84 \\
657\end{array}$ & $\begin{array}{l}51,56 \\
55,08\end{array}$ & $\begin{array}{l}0,22 \\
0,10\end{array}$ & $\begin{array}{l}51,6 \\
55,0\end{array}$ & $\begin{array}{l}1,98 \\
2,54\end{array}$ & $\begin{array}{l}4 \% \\
5 \%\end{array}$ & $\begin{array}{l}47,5 \\
48,1\end{array}$ & $\begin{array}{l}56,6 \\
61,8\end{array}$ & $\begin{array}{l}0,42 \\
0,19\end{array}$ \\
\hline
\end{tabular}

Graphs 1,2, and 3 show the distribution of the results, as well as their compatibility in relation to the normal curve.

Graph 1:- Distribution of the variables in the female population in the 3 courses, and compatibility with the normal curve.

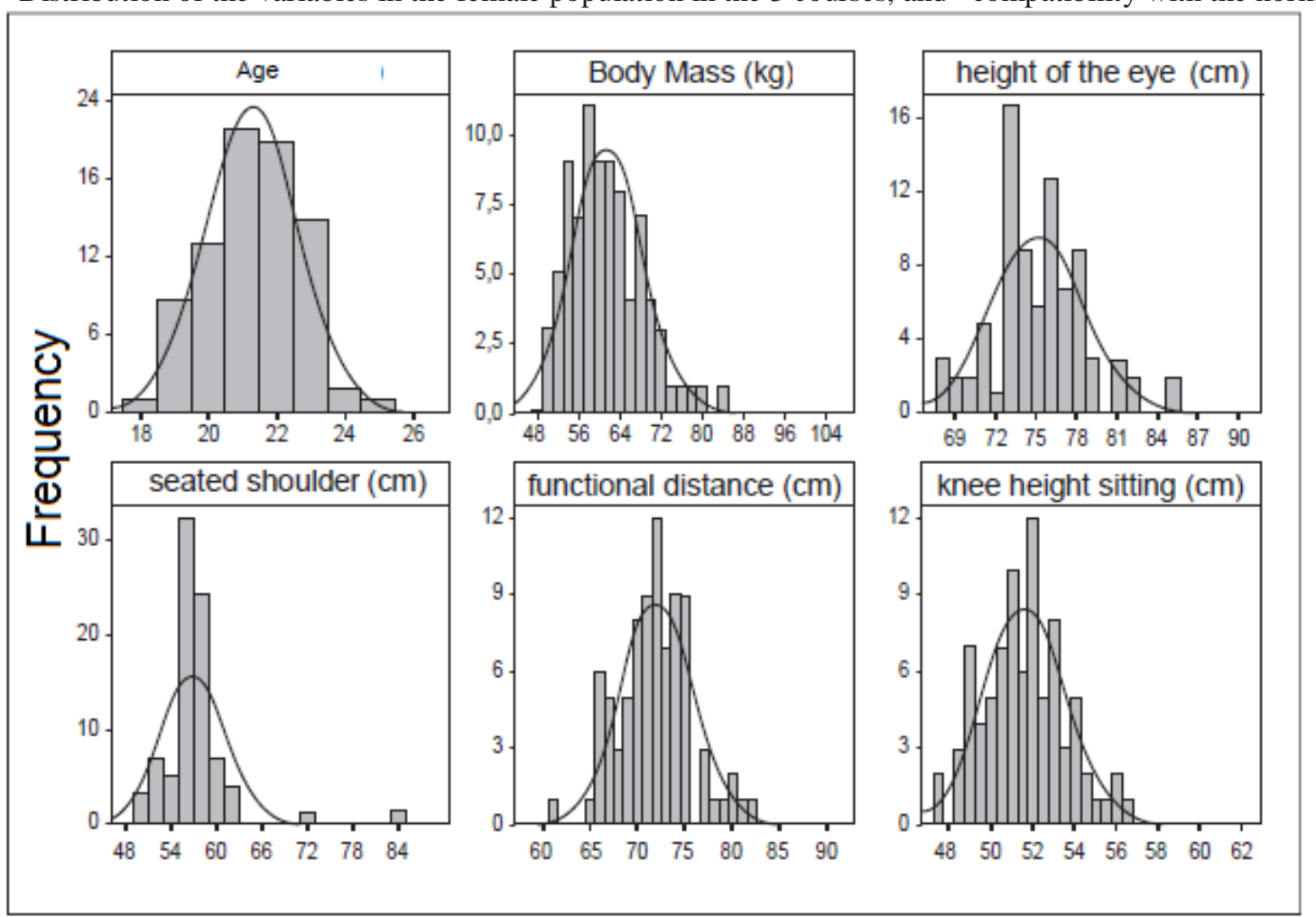


Graph 2:- Distribution of the variables in the male population in the 3 courses, and compatibility with the normal curve.

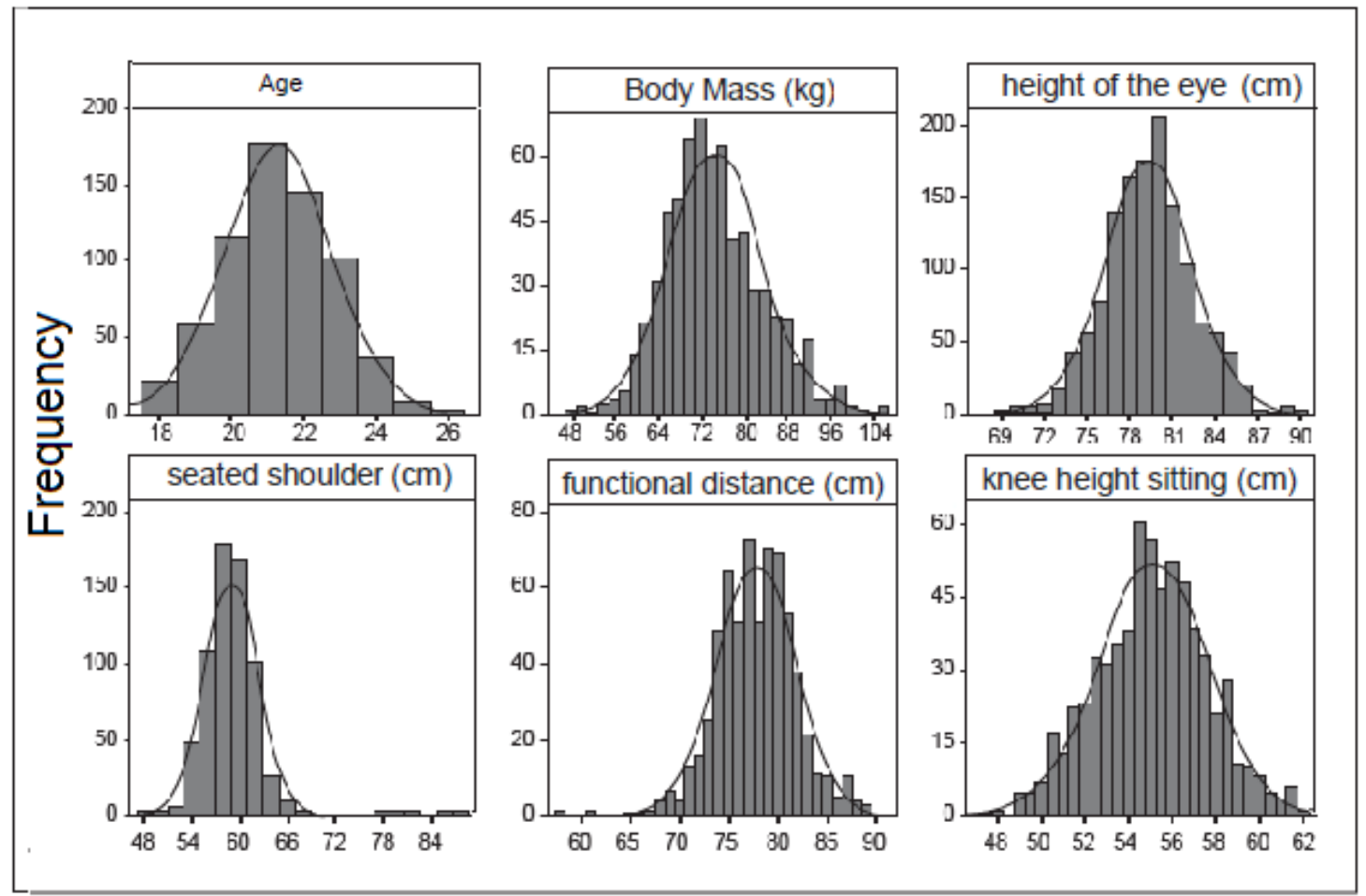

Graph 3:-Blox Plot in the population comprising the CFOAv, CFOIn, and CFOInf.

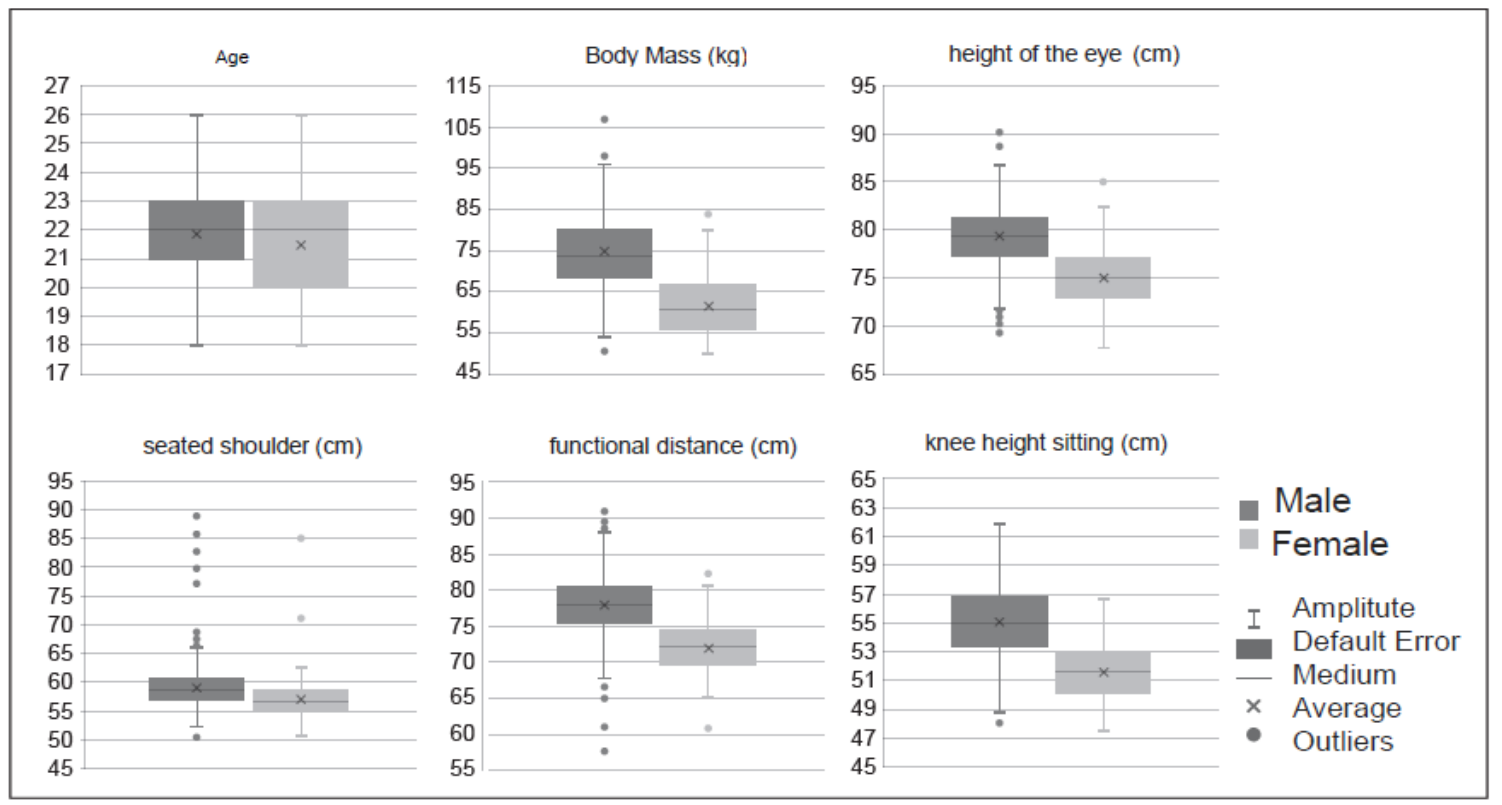

In Table 4, the results of the analysis of the cadet population can be observed, as in Graphs 4, 5, and 6, allowing an overview of the distribution of the 50 measures of sitting height, height, and distance from the knee to the hip in the cadet steward and infantry population, by sex. 
Table 4:-Results of the population evaluated (CFOIn and CFOInf)

\begin{tabular}{|l|l|l|l|l|l|l|l|l|l|l|}
\hline Variable & Sex & $\mathrm{N}$ & average & $\begin{array}{l}\text { standard } \\
\text { error }\end{array}$ & median & $\begin{array}{l}\text { standard } \\
\text { deviation }\end{array}$ & Cv & Min & Max & Ic \\
\hline Age & Female & 66 & 21,45 & 0,18 & 22,0 & 1,44 & $7 \%$ & 18,0 & 25,0 & 0,35 \\
& Male & 183 & 21,84 & 0,11 & 22,0 & 1,51 & $7 \%$ & 18,0 & 26,0 & 0,22 \\
\hline Stature (cm) & Female & 66 & 163,90 & 0,77 & 163,3 & 6,29 & $4 \%$ & 151,6 & 183,2 & 1,52 \\
& Male & 183 & 175,07 & 0,52 & 175,0 & 7,05 & $4 \%$ & 159,1 & 193,0 & 1,02 \\
\hline $\begin{array}{l}\text { Seated height } \\
\text { (cm) }\end{array}$ & Female & 66 & 86,28 & 0,46 & 85,7 & 3,73 & $4 \%$ & 78,7 & 97,2 & 0,90 \\
\hline $\begin{array}{l}\text { Distance } \\
\text { between knee } \\
\text { and hip }\end{array}$ & Male & 183 & 91,27 & 0,26 & 91,2 & 3,47 & $4 \%$ & 81,1 & 100,7 & 0,50 \\
\hline
\end{tabular}

Grafic 4:- Distribution of the variables in the female sample in CFOINT and compatibility in the normal curve

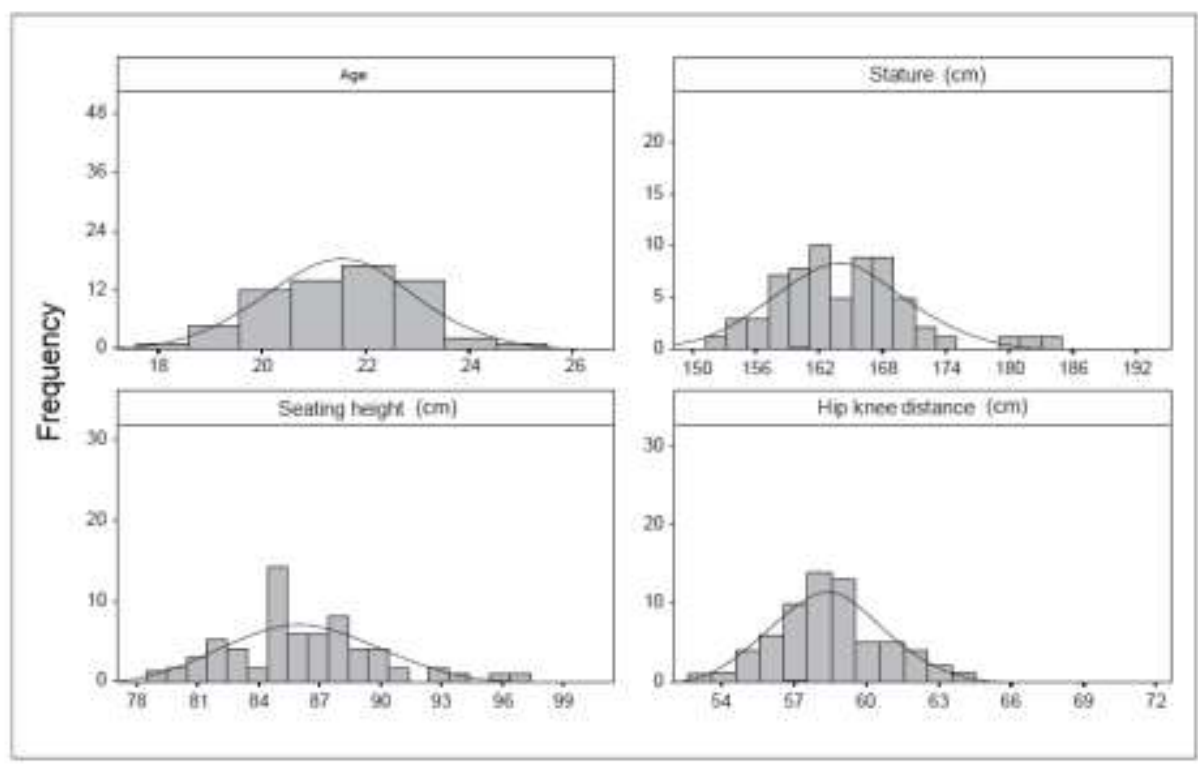

Grafic 5:- Distribution of the variables in the male sample in CFOINT/ CFOINF and compatibility in the normal curve

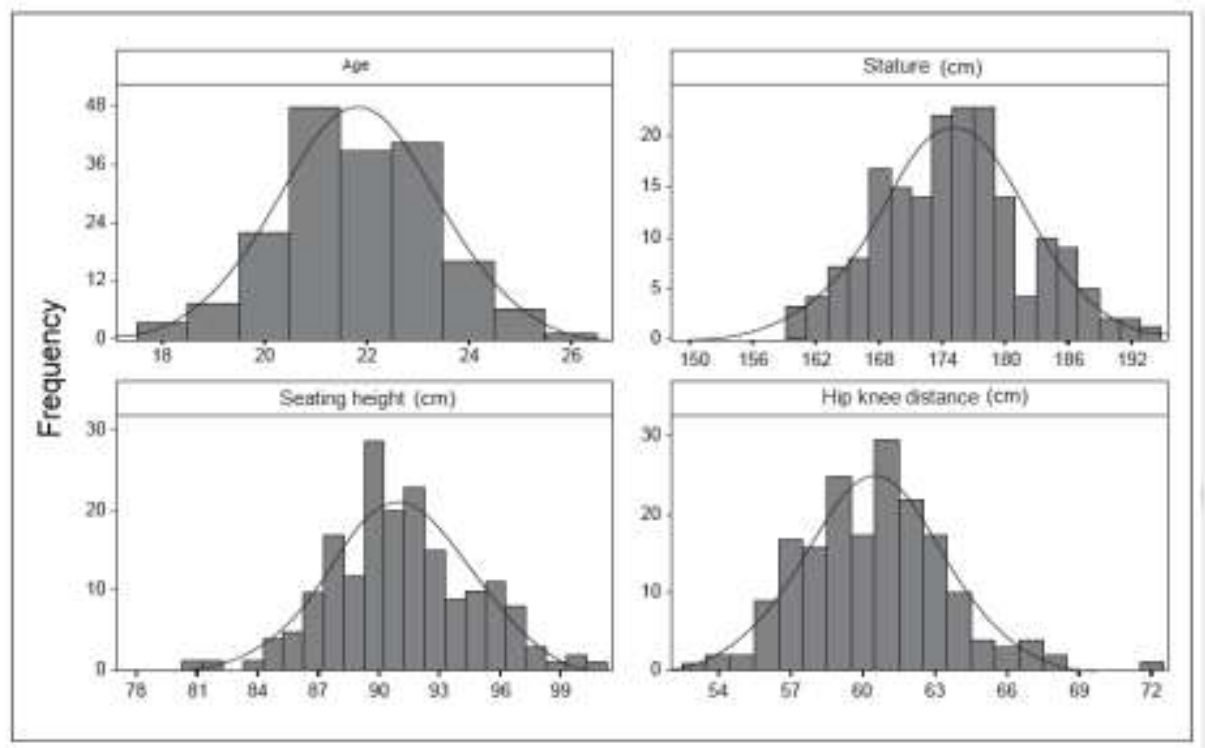


Grafic 6:-Box - Plot of the popolutins CFOInt and CFOint

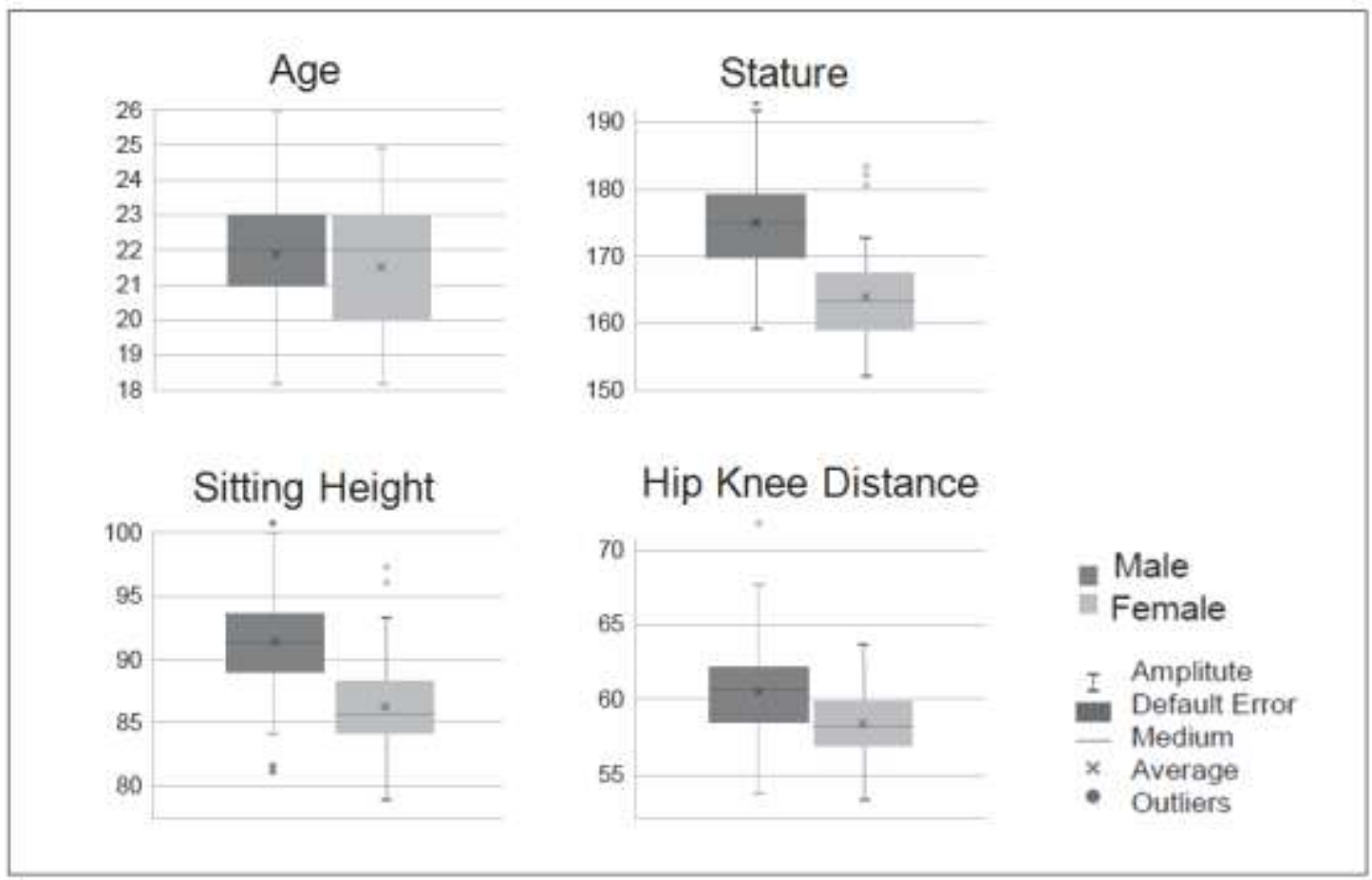

When comparing the sexes, for didactic purposes, the terms suitable or unsuitable, according to the anthropometric limits recommended in the Tucano T-27 Aircraft Manual (Table 1, presented in the Introduction) will be used. Table 5 presents the comparison of suitability between the two sexes for all anthropometric measures analyzed, for both samples.

Table 5:-Results of the population evaluated (CFOInt and CFOInf)

\begin{tabular}{|c|c|c|c|c|c|c|}
\hline \multirow{2}{*}{$\begin{array}{l}\text { Variable } \\
\text { Body mass }\end{array}$} & & \multicolumn{2}{|c|}{$\begin{array}{l}\text { Female } \\
\mathrm{N}\end{array}$} & \multicolumn{2}{|c|}{ Male } & \multirow{2}{*}{$\begin{array}{l}\text { P-valor } \\
<0,001\end{array}$} \\
\hline & $\begin{array}{l}\text { Able } \\
\text { Not Able }\end{array}$ & $\begin{array}{l}51 \\
33 \\
\end{array}$ & $\begin{array}{l}60,7 \% \\
39,3 \% \\
\end{array}$ & $\begin{array}{l}636 \\
21\end{array}$ & $\begin{array}{l}96,8 \% \\
3,2 \%\end{array}$ & \\
\hline $\begin{array}{l}\text { Height of the eye position } \\
(\mathrm{cm})\end{array}$ & $\begin{array}{l}\text { Able } \\
\text { Not Able }\end{array}$ & $\begin{array}{l}52 \\
32 \\
\end{array}$ & $\begin{array}{l}61,9 \% \\
38,1 \% \\
\end{array}$ & $\begin{array}{l}629 \\
28\end{array}$ & $\begin{array}{l}95,7 \% \\
4,3 \%\end{array}$ & $<0,001$ \\
\hline Seated shoulder height & $\begin{array}{l}\text { Able } \\
\text { Not Able }\end{array}$ & $\begin{array}{l}70 \\
14 \\
\end{array}$ & $\begin{array}{l}83,3 \% \\
16,7 \%\end{array}$ & $\begin{array}{l}619 \\
38\end{array}$ & $\begin{array}{l}94,2 \% \\
5,8 \%\end{array}$ & $<0,001$ \\
\hline Functional distance & $\begin{array}{l}\text { Able } \\
\text { Not Able }\end{array}$ & $\begin{array}{l}17 \\
67\end{array}$ & $\begin{array}{l}20,2 \% \\
79,8 \%\end{array}$ & $\begin{array}{l}528 \\
129\end{array}$ & $\begin{array}{l}80,4 \% \\
19,6 \%\end{array}$ & $<0,001$ \\
\hline Knee height seated & $\begin{array}{l}\text { Able } \\
\text { Not Able }\end{array}$ & $\begin{array}{l}58 \\
26 \\
\end{array}$ & $\begin{array}{l}69,0 \% \\
31,0 \%\end{array}$ & $\begin{array}{l}612 \\
45\end{array}$ & $\begin{array}{l}93,2 \% \\
6,8 \%\end{array}$ & $<0,001$ \\
\hline Stature & $\begin{array}{l}\text { Able } \\
\text { Not Able }\end{array}$ & $\begin{array}{l}30 \\
36 \\
\end{array}$ & $\begin{array}{l}45,5 \% \\
54,5 \% \\
\end{array}$ & $\begin{array}{l}164 \\
19 \\
\end{array}$ & $\begin{array}{l}89,6 \% \\
10,4 \% \\
\end{array}$ & $<0,001$ \\
\hline Seated height & $\begin{array}{l}\text { Able } \\
\text { Not Able }\end{array}$ & $\begin{array}{l}42 \\
24 \\
\end{array}$ & $\begin{array}{l}63,6 \% \\
36,4 \% \\
\end{array}$ & $\begin{array}{l}171 \\
12 \\
\end{array}$ & $\begin{array}{l}93,4 \% \\
6,6 \% \\
\end{array}$ & $<0,001$ \\
\hline $\begin{array}{l}\text { Distance between knee and } \\
\text { hip }\end{array}$ & $\begin{array}{l}\text { Able } \\
\text { Not Able }\end{array}$ & $\begin{array}{ll}61 \\
5\end{array}$ & $\begin{array}{l}92,4 \% \\
7,6 \% \\
\end{array}$ & $\begin{array}{l}170 \\
13 \\
\end{array}$ & $\begin{array}{l}92,9 \% \\
7,1 \%\end{array}$ & 0,889 \\
\hline
\end{tabular}

Graphs 7 and 8 present the fitness comparisons in a way that can be more easily visualized. 
Grafic 7:- Comparison between sexes in the distribution of apt

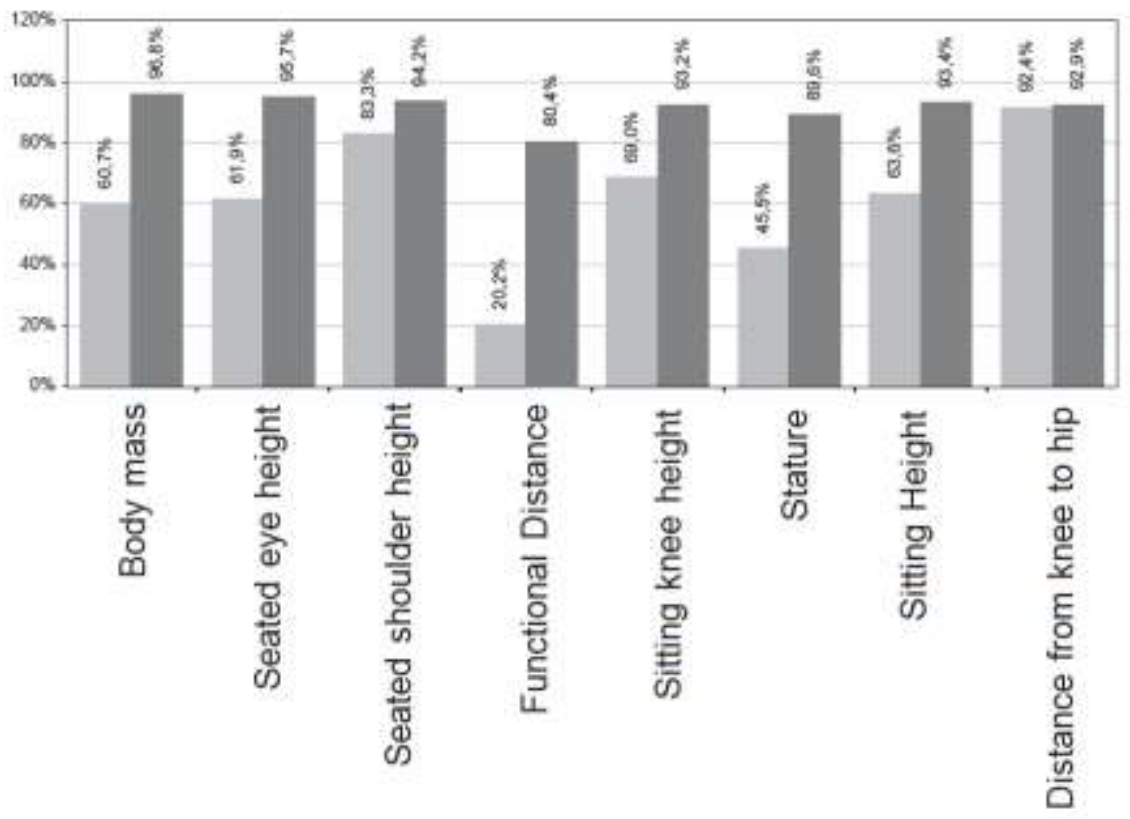

* Female $\quad$ Male

Grafic 8:-Comparison between sexes in the distribution of no apt

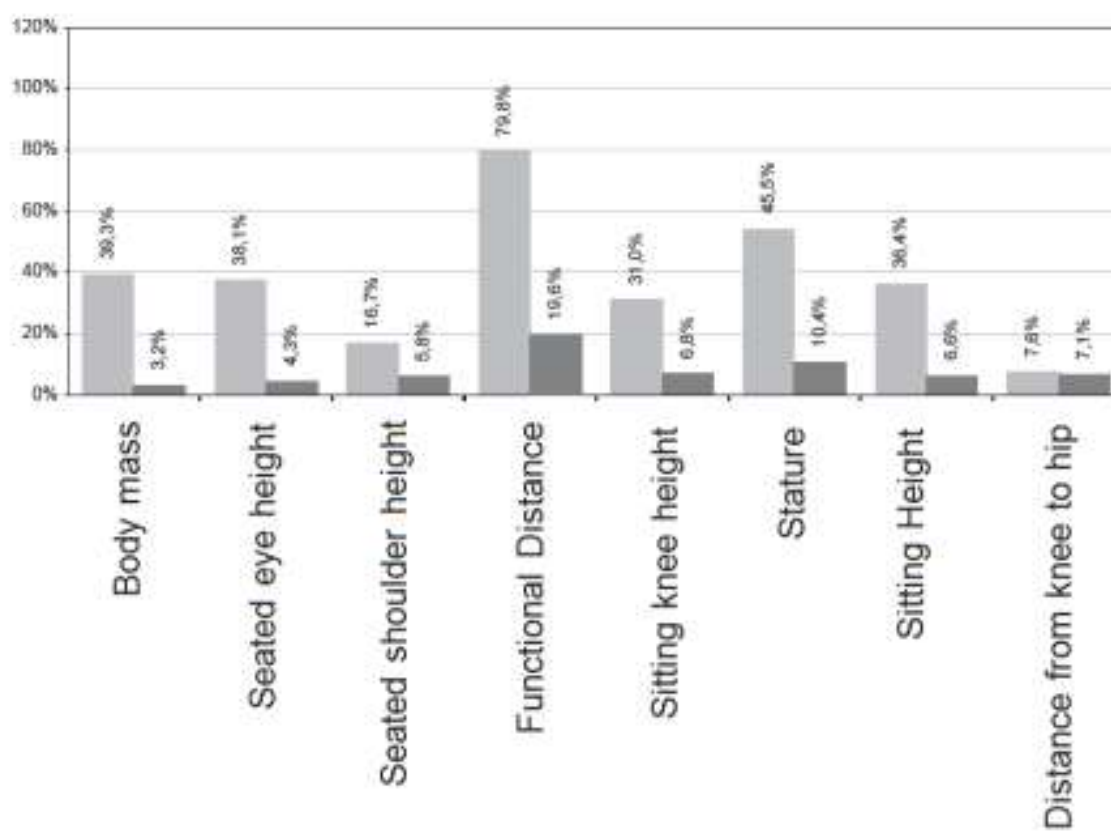

- Female

In Male

The measures corresponding to the $5^{\text {th }}$ and $95^{\text {th }}$ percentiles for both sexes are presented in tables 7 and 8 , referring to the percentage distribution for each variable, by sex. 
Table 6:-Measures corresponding to the 5 th and 95 th percentiles of the male population

\begin{tabular}{|l|l|l|}
\hline Variable & Percentile 5 & Percentile 95 \\
\hline Body Mass $(\mathrm{kg})$ & 62,15 & 90,30 \\
\hline Height of the eye position $(\mathrm{cm})$ & 74,40 & 84,50 \\
\hline Seated shoulder height $(\mathrm{cm})$ & 54,40 & 63,70 \\
\hline Functional distance $(\mathrm{cm})$ & 71,70 & 84,50 \\
\hline Knee height seated $(\mathrm{cm})$ & 50,70 & 59,30 \\
\hline Stature $(\mathrm{cm})$ & 163,90 & 187,00 \\
\hline Seated height $(\mathrm{cm})$ & 86,20 & 96,90 \\
\hline Distance between knee and hip $(\mathrm{cm})$ & 56,30 & 65,80 \\
\hline
\end{tabular}

Table 7:-Measures corresponding to the 5 th and 95 th percentiles of the shemale population

\begin{tabular}{|l|l|l|}
\hline Variable & Percentile 5 & Percentile 95 \\
\hline Body Mass $(\mathrm{kg})$ & 51,40 & 74,85 \\
\hline Height of the eye position $(\mathrm{cm})$ & 69,10 & 81,40 \\
\hline Seated shoulder height $(\mathrm{cm})$ & 51,90 & 61,70 \\
\hline Functional distance $(\mathrm{cm})$ & 66,20 & 79,27 \\
\hline Knee height seated $(\mathrm{cm})$ & 48,80 & 55,20 \\
\hline Stature $(\mathrm{cm})$ & 154,70 & 173,00 \\
\hline Seated height $(\mathrm{cm})$ & 80,60 & 93,40 \\
\hline Distance between knee and hip $(\mathrm{cm})$ & 54,90 & 63,00 \\
\hline
\end{tabular}

\section{Discussion:-}

The variables age, body mass, height of the position of the eyes, sitting height, functional distance (upper limb), sitting knee height, height, sitting height, and distance from the knee to the hip of young Brazilians (men and women) who joined the AFA were analyzed. After the analysis, the individuals were classified according to the anthropometric limits established for the Tucano T-27 aircraft and the percentage of suitability between the sexes was compared. In addition, the distributions of the percentages of the measurements obtained from the male and female populations were compiled, comparing them with the anthropometric limits established in the aircraft manual, in order to verify if the values between the $5^{\text {th }}$ and $95^{\text {th }}$ percentiles in the population met the measurements of the cockpit of the T-27. An age range between 18 and 26 years of age was observed, an outcome already expected, since the BAF establishes the age limit for admission to the cadet post at between 17 and 22 years. The study by Sharma; Raju; Agarwal ${ }^{5}$, who analyzed the anthropometric variables of aspiring fighter pilots of the Indian Air Force, has the closest age range to the present study, between 21 and 22 years $( \pm 0.68)$.

The other studies carried out on the subject of anthropometric analysis in military aviation covered diverse age groups, among which Avila ${ }^{6}$, in a comparative study of three United States Airforce databases, analyzed males between 18 and 68 years of age; Gordon and Licina ${ }^{7}$, analyzed female pilots from the United States Army between 22 and 46 years; Novais-Shimano; Gasparini; Fonseca ${ }^{8}$, analyzed the anthropometric profile of the Brazilian Air Force (BAF) Air Force Demonstration Squadron (ADS), with a mean of 34.1 ( \pm 3.8) years of age; and Paquette; Gordon; Bradtmiller', analyzed the anthropometric profile of individuals between 17 and 36 years of age from the United States Army, of both sexes, comparing it to an earlier anthropometric profile.

Analysis of the body mass variable indicated that $60.7 \%$ of the women were considered suitable, while $96.8 \%$ of the men were within the limits established for the Tucano T-27. According to Novais-Shimano; Gasparini; Fonseca ${ }^{8}$, body mass is determinant in cases of ejection, leading to severe lesions when the upper limit is extrapolated and being impossible to perform when the subject is below the lower limit. The authors also point out that the occurrence of body mass below the lower limit is common among women, which was ratified by the result of the present study, since the maximum value identified was $83.8 \mathrm{~kg}$ (below the upper limit), however, 39.3\% of the cadets were considered unsuitable, which shows that they were ranked below the lower limit of body mass.

According to the results, $61.9 \%$ of the women were suitable for the variable sitting eye height, while $95.7 \%$ of the men were suitable in the same condition. According to Zehner and Hudson, ${ }^{10}$ a sitting eye height below the ideal may restrict the visual field of the pilot, making it impossible to see the runway during landing. Novais-Shimano; Gasparini; Fonseca ${ }^{8}$ evidenced the appropriateness of the position of the pilot in relation to their external (referring 
to the visualization of other aircraft) and internal visual field (referring to the visualization of the internal commands), called projected position for the eyes.

The variable sitting shoulder height demonstrated $83.3 \%$ of women and $94.2 \%$ of men as suitable. Sharma et al. ${ }^{5}$ found significant differences in this variable when comparing measurements of the male military population in 2011 to two previous anthropometric databases, one from the United States Air Force (USAF) in 1967 and the other from 1988, the Joint Primary Aircraft Training System (JPATS). According to Novais-Shimano; Gasparini; Fonseca ${ }^{8}$, pilots with a lower shoulder height measure can maintain a posture well supported on the seat back, although in some cases there may be a need to perform trunk pre-positioning to reach the joystick for maneuvering.

Among the women, the results of functional distance presented $89.3 \%$ unsuitable individuals and only $10.7 \%$ suitable. The female percentage is very discrepant when compared to males, who presented 70.6\% suitability (p $<0.001)$. The T-272 Manual does not consider this variable as a critical anthropometric measurement since it is not

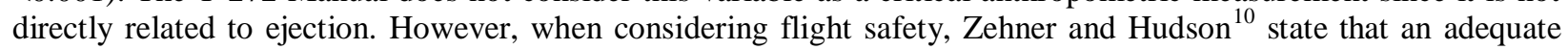
functional distance ensures that the pilot is able to reach and operate the hand controls to safely fly an aircraft under both normal and negative $G$ conditions. Novais-Shimano; Gasparini; Fonseca ${ }^{8}$ emphasize the importance of effective control of the joystick without having to perform postural adjustments, a situation that, in the long run, can cause injuries to the spine.

The sitting knee height indicated $69 \%$ suitability for women and $93.2 \%$ for men. For Zehner and Hudson ${ }^{10}$, sitting knee height should not be analyzed in isolation, since it is directly associated with distance from the knee to the hip (which is called combo leg), allowing analysis of the functional reach of the lower limb. Gordon and Licina ${ }^{7}$ found significantly lower mean values of sitting knee height (in relation to the other measures analyzed) in the US military of the 1995 database when compared to the US military of the 1988 database $(-1.46 \mathrm{~cm})$.

The only variable that did not demonstrate a statistically significant difference between the suitable and unsuitable percentages was the height of the women, who presented, respectively, $45.5 \%$ and $54.5 \%$. Among the men, $89.6 \%$ were considered suitable. Sharma et al. ${ }^{5}$ conducted a comparative study in the United States Air Force (USAF) using anthropometric measurements collected in the year 2011, the USAF 1967 anthropometric database, and the anthropometric database of the Joint Primary Aircraft Training System (JPATS) of 1988; in this study it was evidenced that the male population of Caucasian crew members has been growing significantly. In the study by Gordon and Licina ${ }^{7}$, who compared the anthropometric data of United States Army women from 1988 and 1995 , the average height of the female population was $15.18 \mathrm{~cm}$ lower in 1995.

The results of the sitting height analysis showed that only the women presented a lower percentage of suitability than expected, $63.6 \%$, whereas for men the suitability was $93.4 \%$ of the individuals. Sharma; Raju; Agarwa consider this measurement one of the most important in the performance of static anthropometry analysis to verify the compatibility of pilots to aircraft. When the sitting height of the individual is adequate, the space between the head and the canopy is maintained on routine flights, with no compromising of proper posture for ejection, and both the visual field and reach of the controls can be guaranteed ${ }^{5,10}$.

In the analysis of the comparisons between the sexes, no statistical difference was found only in the distribution of knee to hip distance $(\mathrm{p}=0.899)$, since both sexes presented a percentage of suitability of around $92 \%$. Sharma; Raju; Agarwa ${ }^{5}$ and Zehner Hudson ${ }^{4}$ associate this variable with the safety of the pilot in case of ejection and also with the knee clearance in the control of the joystick, allowing the pilot to operate the controls safely. In addition, knee to hip distance, associated with sitting knee height, directly interferes with the functional reach of the pedals ${ }^{10}$.

Moreira $^{11}$ and Silva ${ }^{12}$, referring to cockpit design projects, confirmed the importance of establishing the limits to accommodate $90 \%$ of the population, the minimum limit being an anthropometric dimension determined by the $5^{\text {th }}$ percentile and the maximum determined by the $95^{\text {th }}$ percentile of the population for which the job is being developed.

Analysis of the distribution of the percentiles of the male population showed that the values between the $5^{\text {th }}$ and $95^{\text {th }}$ percentile met the measurements of the T-27 cockpit in almost all the anthropometric dimensions, except for functional distance, whose minimum limit $(74.6 \mathrm{~cm})$ corresponded to the $19.5^{\text {th }}$ percentile of the population, and distance from knee to hip, whose maximum limit $(65.20 \mathrm{~cm})$ corresponded to the $93.4^{\text {th }}$ percentile. The other 
dimensions (body mass, height of the eye position, sitting shoulder height, sitting knee height, height, and sitting height) met the anthropometric requirements of the aircraft, within the recommended parameters.

Adversely, the values between the $5^{\text {th }}$ and $95^{\text {th }}$ percentiles in the female population were not compatible, in any of the analyzed dimensions, with the minimum anthropometric requirements of the T-27 aircraft. Thus, for the female population, the minimum limits corresponded, respectively, to the $38.5^{\text {th }}$ percentile of body mass; $38.5^{\text {th }}$ of the height of the eye position; $14.4^{\text {th }}$ of sitting shoulder height; $80.7^{\text {th }}$ of functional distance; $31.3^{\text {rd }}$ of sitting knee height; 55.3 ${ }^{\text {rd }}$ of height; $36.9^{\text {th }}$ of sitting height; and $7.6^{\text {th }}$ of knee to hip distance.

\section{Conclusions:-}

The criteria for selecting pilots to join the Brazilian Air Force are still used as a way to ensure operational and flight safety, based on the anthropometric limits established by the Flight Manual of the aircraft themselves, such as the Tucano T-27 aircraft used for advanced flight training of Air Force Academy pilots.

In addition to encompassing $90 \%$ of the target population for whom the aircraft is destined, distributed between the $5^{\text {th }}$ and $95^{\text {th }}$ percentiles, allowing an individual of greater or lesser anthropometric proportions to operate the aircraft safely and efficiently, the use of anthropometric criteria for the entry of pilots should provide equal opportunity for both sexes and serve as a criterion for the definition of ergonomic requirements for the modernization, construction, and acquisition of new aircraft.

In the present study, it was evidenced that the cockpit of the Tucano T-27 aircraft accommodated more than $90 \%$ of the Brazilian young people who wanted to join the AFA, $92.9 \%$ of the men and $92.4 \%$ of the women, for the measurement of distance from the knee to the hip.

The functional distance (upper limb), essential for flight safety when piloting the Tucano T-27 aircraft and defined by the dimensions of its cockpit, was not compatible with measurements found in at least $90 \%$ of the population of male and female cadets (ranging between the $5^{\text {th }}$ and $95^{\text {th }}$ percentiles), with $80.4 \%$ of men and $20.2 \%$ of women being unsuitable. The same was verified for the height parameter, for which $89.6 \%$ of the men and $45.5 \%$ of the women were considered suitable.

In the other anthropometric limits, the suitability percentages of the male and female population were, respectively, $96.8 \%$ and $60.7 \%$ for body mass; $95.5 \%$ and $61.9 \%$ for the height of the eye position; $94.2 \%$ and $83.3 \%$ for sitting shoulder height; $93.2 \%$ and $69.0 \%$ for sitting knee height; and $93.4 \%$ and $63.6 \%$ for 60 sitting height. These results showed that the male population presented greater suitability (above 90\%) in relation to the female population (below 90\%).

It was evidenced that, although there were cadets considered suitable, according to the Tucano T-27 manual, this suitability did not refer to the population analyzed, since values between the $5^{\text {th }}$ and $95^{\text {th }}$ percentile in the population were not compatible with all anthropometric requirements of the aircraft. In the female population, it should be noted that the minimum limit of all dimensions was above the $5^{\text {th }}$ percentile, while in the male population the minimum limit did not reach the $5^{\text {th }}$ percentile in functional distance and the $95^{\text {th }}$ percentile exceeded the maximum limit in the knee to hip distance.

This information emphasizes the need for new analyzes of the national anthropometric profile, aiming at optimizing utilization without risk of injury due to inadequacy of the cockpit dimensions and providing information on the target population in the elaboration of future aircraft projects.

\section{Conflict Of Interest:-}

The authors declare that they have no conflict of interest. 


\section{References:-}

1. EJECTION MEDIA. Martin-Braker, 2015. Disponível em: <http://www.martin-baker.com/ejectionmedia\#prettyPhoto[pp_gallery]/2/>. Acesso em: 21 jan. 2016.

2. EMBRAER. Manual de Voo do Avião T-27 EMB-312 Tucano. Publicação O.T. 1T27-1. São José dos Campos, SP: EMBRAER, 2008.

3. MARTIN-BAKER. Manual do assento ejetor: MK8LC.Londres: [s.n.], 2012.

4. BRASIL. Estado Maior da Aeronáutica. Manual de medidas antropométricas, Brasília, DF, 2013.

5. Sharma S, Raju K, Agarwal A. Static anthropometry: Current practice determine aircrew air craft compatibility. Ind J Aerospace Med 2007; 51(2): 40-47.

6. AVILA, J. A. de. Tendência secular de estatura, peso e índice de massa corporal em adultos jovens militares brasileiros no século XX. 2013. 111 f. Dissertação (Mestrado em Ciências) - Faculdade de Ciências Médicas, Universidade Estadual de Campinas, Campinas, 2013.

7. GORDON CC, LICINA JR. US Army Female Aviator Anthropometric, Clothing, and Cockpit Compatibility Study:emography and Anthropometry of the Study Cohort. [s.l.]: U.S. Army Aeromedical Research Laboratory, 1999.

8. NOVAIS-SHIMANO SG, GASPARINI JN, FONSECA M de CR. Relação Entre Antropometria dos Pilotos e Geometria do Cockpit da Aeronave EMB 312 T-27 Tucano: uma Visão Ergonômica. Brazilian Journal of Biomechanics=Revista Brasileira de Biomecânica 2010; 11(20): 57-72.

9. PAQUETTE, S.; GORDON, C.; BRADTMILlER, B. Anthropometric Survey (ANSUR) II Pilot Study: Methods and Summary Statistics. Ohio: Anthrotech, 2009.

10. ZEHNER, G. F.; HUDSON, J. A. Body Size Accommodation in USAF Aircraft. EUA: Air Force Research Laboratory, 2002.

11. MOREIRA, S. B. Banco de dados antropométricos de aeronautas brasileiros do sexo masculino. In: SEMINÁRIO DE ESTUDOS: PODER AEROESPACIAL \& ESTUDOS DE DEFESA, 3., 2010, Rio de Janeiro. Anais. Rio de Janeiro: UNIFA, 2010. p. 203-216. Disponível em: http//:www.unifa.aer.mil.br/posgrad/docs/anais_iii_seminario_2010.pdf >. Acesso em: 20 ago. 2013.

12. SILVA GV. Requisitos ergonômicos em aviação: importância e aplicações para a FAB. Revista da UNIFA, Rio de Janeiro 2009; 21(24): 84-103.

13. Autor responsável: Thiago Augusto Rochetti Bezerra, Endereço para correspondência: Universidade da Força Aérea, Programa de Pós-graduação em Desempenho Humano Operacional, Av. Marechal Fontenelle, 1200, Campos dos Afonsos.

14. Rio de Janeiro/RJ - CEP: 21.740-002 (019-997678229) e-mail: thiago_rochetti@globomail.com 